\title{
Congenital hypertrophy of retinal pigment epithelium
}

\author{
Ofira Zloto, Iris Moroz, Vicktoria Vishnevskia-Dai
}

Ocular Oncology Unit, Goldschleger Eye Institute, Sheba Medical Center, Tel Hashomer, affiliated to the Sackler Faculty of Medicine, Tel Aviv University, Ramat Gan, Israel

\section{Correspondence to} Dr Vicktoria Vishnevskia-Dai; vivida65@gmail.com

Accepted 7 July 2020

\section{DESCRIPTION}

A 45-year-old man was referred to the ocular oncology service for evaluation due to a black asymptomatic lesion in his right eye. His medical history included hyperlipidemia and high myopia. On clinical examination, a flat black lesion that looked like a flower was observed (figure 1A,B). The lesion did not resemble melanoma. Moreover, ultrasound examination confirmed that the lesion was flat. The lesion showed hypoautofluorescence at the dark parts that correlate with the known histopathologic evidence of lack of lipofuscin in the retinal pigment epithelium of congenital hypertrophy of retinal pigment epithelium (CHRPE) and mild hyperautofluorescence that correlate with

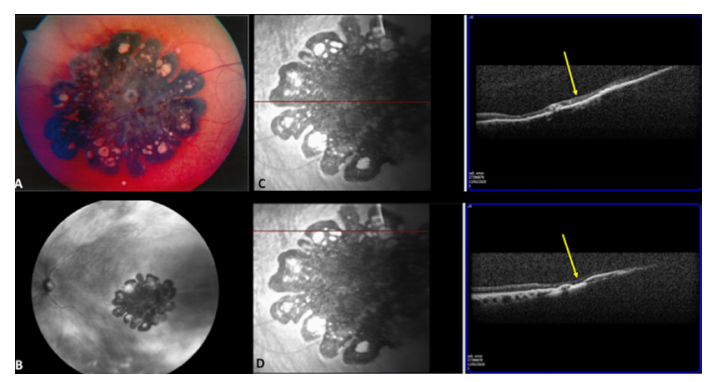

Figure 1 Flower of congenital hypertrophy of retinal pigment epithelium (CHRPE). (A) Colour fundus photography - a black flat lesion in the peripheral retina resembling a flower. (B) An autofluorescence imagethe lesion shows hypoautofluorescence that correlates with the known histopathologic evidence of lack of lipofuscin in the retinal pigment epithelium of CHRPE. The lacunae show mild hyperautofluorescence that correlates with scleral autofluorescence. (C) Optical coherence tomography (OCT) with a raster line on the lesion area - a loss of the external retinal layers is depicted. (D) OCT with a raster line on the lacunae area-no retina is seen in the lacunae area.

\section{Patient's perspective}

Feel well, arrive to annually follow-up.

\section{Learning points}

- Classic congenital hypertrophy of retinal pigment epithelium (CHRPE) is usually unifocal, benign, pigmented lesion located at the level of the retinal pigment epithelium.

- On optical coherence tomography, CHRPE is flat with irregular external retinal layers in the pigmented portion and absent external retinal layers in the lacunae area.

- All patients with CHRPE should be asked about colon cancer and diseases in their family.

scleral autofluorescence at the lacunae (figure 1B). In optical coherence tomography, a loss of the external retinal layers was seen in the area of the lesion (figure 1C) and no retina was seen in the lacunae' area (figure 1D). The diagnosis was confirmed as CHRPE.

In revised anamnesis, no positive familial history of polyps, Gardner syndrome or colon cancer was noted.

Contributors OZ: planning, conduct, reporting, conception and design, analysis and interpretation of data. IM: conduct. VV-D: planning, conduct, reporting, conception and design and interpretation of data.

Funding The authors have not declared a specific grant for this research from any funding agency in the public, commercial or not-for-profit sectors.

Competing interests None declared.

Patient consent for publication Obtained.

Provenance and peer review Not commissioned; externally peer reviewed.

Copyright 2020 BMJ Publishing Group. All rights reserved. For permission to reuse any of this content visit

https://www.bmj.com/company/products-services/rights-and-licensing/permissions/

BMJ Case Report Fellows may re-use this article for personal use and teaching without any further permission.

Become a Fellow of BMJ Case Reports today and you can:

- Submit as many cases as you like

- Enjoy fast sympathetic peer review and rapid publication of accepted articles

- Access all the published articles

- Re-use any of the published material for personal use and teaching without further permission

Customer Service

If you have any further queries about your subscription, please contact our customer services team on +44 (0) 2071111105 or via email at support@bmj.com.

Visit casereports.bmj.com for more articles like this and to become a Fellow 